\title{
Data Envelopment Analysis of Higher Education Competitiveness Indices in Europe
}

\author{
József Kabók ${ }^{1}$, Tibor Kis ${ }^{2}$, Maria Csüllög ${ }^{2}$, Imre Lendák ${ }^{3}$ \\ 1 Provincial Secretariat for Science and Technological Development, Bulevar \\ Mihajla Pupina 16, 21000 Novi Sad, Serbia \\ Jozef.Kabok@vojvodina.gov.rs \\ 2 University of Novi Sad, Faculty of Economics, Segedinski put 9 -11, 24000 \\ Subotica, Serbia \\ tkis@ef.uns.ac.rs; cilegm@ef.uns.ac.rs \\ 3 University of Novi Sad, Faculty of Technical Sciences, Dositeja Obradovića 6, \\ 21000 Novi Sad, Serbia \\ lendak@uns.ac.rs
}

\begin{abstract}
In this paper, the data envelopment analysis method is used to examine the competitiveness of higher education in selected countries / regions in Europe. The competitiveness of higher education is analyzed on the basis of available information on the chosen indicators, interacting with a model of investment which is applied in the field of higher education. The purpose of the research is to determine the level of competitiveness of higher education of the Republic of Serbia and its Autonomous Province of Vojvodina, as a European region, compared to selected European countries. The research results indicate that the application of the new investment model would improve the unsatisfactory competitiveness of the higher education of the Republic of Serbia and AP Vojvodina. Because of the large differences in the competitiveness of higher education among the analysed countries / regions, the research results point to the need for a unified approach in creating a development strategy and improving the competitiveness of higher education in Europe.
\end{abstract}

Keywords: competitiveness index; investment model; higher education

\section{Introduction}

Higher education is of particular importance for the economic competitiveness of any society, as higher education institutions generate knowledge and develop expertise and skills which enable individuals to achieve their personal goals as well as become valuable members of society. The competitiveness of higher education should be implemented so that it can be enjoyed by all institutions, regions and countries, and contribute to a global society based on education [25]. 
The choice of a higher education investment model has a decisive impact on the competitiveness of higher education. It is shown that the quality of teaching, the scope and structure of investment, the number of students as well as the competitiveness of higher education all depend on the investment model. Different investment models result from the social conditions in certain countries, the method of implementation of the Bologna Declaration [24], as well as historical, educational and cultural characteristics. The choice of the investment model depends on the budget capacity but also on the commitment of the state regarding the amount of public funds spent on investment in higher education.

Investment in higher education in Serbia is insufficient. In 2010, it amounted to $€ 1,201.90$ of budgetary resources per student [22], and in AP Vojvodina, as a European region, $€ 1,076.60$ per student [22]. Out of the 30 countries/regions analysed (26 countries of the European Union, all countries with the exception of Luxembourg, which could not be included in the research because of the inadequacy of information in the field of higher education, as well as Serbia, AP Vojvodina, Croatia and FYR Macedonia), Serbia was $28^{\text {th }}$, and the AP Vojvodina $29^{\text {th }}$ in front of the FYR of Macedonia [10]. These data indicate the need to implement new investment models for higher education in Serbia, which will encourage investment in higher education, especially in its competitiveness and ability to be a participant in the competitive market of higher education of the European Union.

This paper analyses the state of the competitiveness of higher education in Serbia and AP Vojvodina, through observation and analysis of selected indicators of competitiveness and through calculating the index of competitiveness of higher education. The goal of this paper is to present an overview of the possibilities for increasing the level of the competitiveness of higher education in Serbia by implementing a new investment model.

One of the aims of the present study is an econometric analysis of the rankings of Serbia and AP Vojvodina, in terms of the competitiveness of higher education in relation to the aforementioned European countries in the period from 2006 to 2010. Using econometric analysis, this study determines changes in the rank and competitiveness index of higher education in Serbia and AP Vojvodina in relation to the aforementioned European countries, applying a new model of investment.

Since the present study analyses the competitiveness of higher education, the results are significant for both the professional and the academic community. The importance of the study is also reflected in the fact that higher education has a crucial influence on the creation of a knowledge based society, on learning and on innovation, an important political as well economic goal of all countries of the European Union in line with the Lisbon Agenda [18]. Therefore, the study is important for the strategy-makers in the European area of higher education, but also for development strategy-makers in higher education as well as institutions of higher education in Serbia and AP Vojvodina. 
The paper consists of five chapters. After the introductory section, the second chapter refers to the literature review dealing with related research. The third section describes the research methodology, and the fourth analyses the results of research compared to the index of competitiveness of higher education in the selected countries / regions in Europe. The conclusion, based on the analysis of survey results, proposes measures and activities to the strategy and development policy makers of higher education in the European Union, Serbia and AP Vojvodina, in order to improve the competitiveness of higher education. The conclusion also points to directions for further research in this area, as well as to the limitations of the present study.

\section{Literature Review}

Theoretical discussions on investment in higher education are often limited to oneoff discussions on the details of a particular model of investment, without considering the role and impact of higher education on overall social and economic development and competitiveness. Further, these discussions rarely perceive the performance of individual models from the perspective of a betterquality investment in higher education, nor do they consider the impact of investment on the competitiveness of higher education. Bearing this in mind, the theoretical consideration of investment in higher education begins with a review of the new trends and paradigms of higher education relating to the role, function and impact of higher education on overall social and economic development, as well as on competitiveness.

In the scientific literature, there is a number of different concepts and attitudes about the role and impact of higher education on social development, which points out the fact that there are a large number of parties interested in the optimal functioning of higher education. The views on the role and impact of higher education related to functionalism focus on outcomes in higher education. The representatives of this concept [1], [19] start from the idea of knowledge as the main element of higher education: "knowledge is material, and research and teaching are the main technologies" [1, p. 12].

Representatives of the functional approach to higher education believe that the choice of the most appropriate model of investment in higher education is greatly influenced by the fact that changes and integrations are the most important challenges of higher education. Investment models can be chosen so that the speed of change and the integration of higher education are improved. However, the extent to which a particular investment model can be applied in a given system of higher education is primarily determined by the required measure of change of the education system. 
In academic debates regarding the most appropriate investment model in higher education, there exist both instrumentalist and utilitarian attitudes towards higher education, albeit reductionist regarding the understanding of social reality [11], [20], [6]. Arguments in favour of the application of one of the investment models are based on the expected or actual impact of higher education on social, economic and personal development, particularly in terms of the share of public and private investment in higher education. Authors who advocate for public investment claim that, if it is assumed that employees with a university degree earn more than those who have not attained university degrees, in the case of progressive tax rates on income, employees with a university education will be paying higher taxes. If the future revenue on the grounds of such tax is more than current expenditure, increased public investment in higher education is automatically justified. On the other hand, investment models in higher education where the primary source of income comes from public funds are not considered suitable investment models in higher education by some authors [20], [6]. According to them, such models do not contribute to the prosperity, development and increase of the competitiveness of higher education, and therefore investment models which include both public and private sources of funding are preferred. Del Rey and Racionero [6] believe that a successful and competitive investment in higher education should involve investments from two sources: public, through tax subsidies where higher education costs are paid for from general taxation, and private, where every student pays for their education through loans. They advocate joint investment in higher education, from public and private sources, without stating the optimal proportion of such investment [15].

In the area of economic development, higher education increases productivity and competitiveness, particularly through the growth of the human capital and the creation of a better educated, more qualified and more skilled workforce. In addition, in the knowledge economy, knowledge production, together with the effective and efficient transfer of knowledge to industry (in the broad sense), is one of the key factors for economic growth [13], [4], [17]. The connection between education and economic growth is suggested by other studies [16], with the conclusion that an additional year of schooling leads to an increase in GDP per capita of $4 \%-7 \%$.

Considering the problem of the competitiveness of higher education, some authors [7], [23] state that internationally oriented universities contribute to the competitiveness of countries and thus determine whether countries benefit from globalization, and in what way. A major obstacle to the greater competitiveness of higher education is outdated academic structure and organization of universities, rendering them unable to guarantee academic prestige. Academic competitiveness can be improved by greater investment in higher education, opening national programs of university funding to foreign participants, as well as intensifying transnational programs of higher education financing. 
The amount of tuition paid by students of higher education institutions affects the competitiveness of higher education. In many countries, tuition, i.e. the cost of higher education covered by students, is regulated by the state through a model of investment in higher education. By keeping tuition costs at specified levels, the state tries to make higher education more accessible, and this is the main argument for the implementation of the policy of regulating the price of tuition. Empirically, it turns out, however, that the price flexibility of demand of higher education is elastic [5], meaning that if there is no response to changes in tuition by students, the increase in demand that occurs as a result of regulated tuition fees is limited.

Development trends and tendencies in the field of higher education suggest that the development of the competitiveness of higher education should be directed towards more differentiated higher education systems, especially when there is a broad consensus that it is necessary to establish the country's elite universities. The fact is that the dual objective of mass access and excellence requires a dynamic and competitive sector of higher education [2]. Globalization expands the market of higher education beyond state borders, which increases the competition and demand for higher education. In order to help differentiate on the basis of the quality of higher education, it is believed [12] that higher education institutions should be allowed to choose their own tuition rates.

The analysis of the consequences when institutions are allowed to choose their own fees is particularly accentuated, because the fees in such case would represent actual costs and market situation of higher education. This would certainly encourage competition in the market for higher education. Universities would make an effort to stand out by providing a range of specific programs of study, i.e. a specific combination of price and quality [3]. The difference between supply and demand would be levelled as institutions would become more aware of the real needs of the students and their social demands. This would also encourage competition to attract students (by giving a discount on tuition fees for example), and institutions would try to win over students whose profiles best match the specific study programs in their offering.

It is necessary, however, to note two facts [5]: firstly, there is the possibility of expressing the view that the functioning of any institution of higher education cannot be the same as other companies that operate in the normal open market. While commercial companies mainly operate on the principle of maximizing the profits of their investors, institutions of higher education are mostly looking for the highest quality and for academic reputation. In this regard, it is difficult to expect that the pricing policy of education and tuition, i.e. fees dictated by the higher education institutions, would strictly follow the principle of profit maximization. Secondly, the planned consequences of the deregulation of the prices of tuition fees in higher education would come into play only when the market of higher education is completely free. 
In contrast to the abovementioned studies, which are listed as comparative or similar studies in the area of research, this study deals with the econometric analysis of the competitiveness of higher education in Serbia and in AP Vojvodina, in relation to the competitiveness of 26 countries of the European Union, Croatia and the FYR of Macedonia in the period from 2006 to 2010.

\section{Research Methodology}

The competitiveness index of higher education in the 26 studied countries of the European Union, Serbia and its AP Vojvodina, as a European region, Croatia and FYR Macedonia, is calculated using the modified method modelled on the research methodology of calculating the index of competitiveness of European countries / regions created by Robert Huggins [21]. The aforementioned methodology was originally applied to rank the regions in the UK, as well as the countries / regions in the European Union. The period investigated in this paper is from 2006 to 2010, and the methodology applied involves the use of methods of analysis and synthesis and the use of statistical and mathematical methods, particularly data envelopment analysis (DEA method), which is the application of linear programming method based on the ranking of countries / regions according to individual indicators analysed.

Determining the competitiveness index of the higher education of these countries and AP Vojvodina involves the analysis of the three indicators which are, according to the applied research methodology, in function of the change of competitiveness of higher education:

- The number of students per 1000 population $\left(\mathrm{P}_{1}\right)$;

- 100 - the number of students per 100 employees $\left(\mathrm{P}_{2}\right)$, and

- Budgetary resources per student in $\operatorname{EUR}\left(\mathrm{P}_{3}\right)$.

The study used a modified indicator: 100 - the number of students per 100 employees, in order to avoid the effect of favouring the country / region that has a high unemployment rate.

The DEA method determines the competitiveness index of the higher education of the countries / regions analysed. There are $n$ elements (countries) $E_{i}, i=1,2, \ldots, n$ with $k$ parameters each $P_{i j}, j=1,2, \ldots, k$. The condition of using the calculation methods and the correct interpretation of the results is that the data are consistent, i.e., that the higher value of each indicator has the same positive (or negative) effect on the common indicator; otherwise, it is necessary to calculate the individual indices through the reciprocal value, opposite number or subtraction of a constant. 
The rank of each element is identified by each indicator $R_{i j}$, so that the element with the highest value of the indicator has the rank of 1 and there is an adequate number of points assigned to each rank, so that the element with the highest value of indicators has the highest number of points:

$\mathrm{Y}_{i j}=\mathrm{n}+1-\mathrm{R}_{\mathrm{ij}}$

(1)

where:

$Y_{i j}:$ The number of points of element rank

$\mathrm{R}_{\mathrm{ij}}:$ Element rank

$\mathrm{n}$ : Number of elements

Proxy variables $\mathrm{v}_{\mathrm{j}}$ for each indicator are introduced and a set of $\mathrm{n}$ constraints is formed:

$\sum_{j=1}^{k} R_{i j} v_{j} \leq 1, i=1,2, \ldots, n$

where:

$k$ : Number of indicators

$v_{j}$ : Dummy variables which correspond to certain indicators.

provided that:

$\Theta \leq \mathrm{v}_{\mathrm{j}} \leq 1, \forall \mathrm{j}$

Linear programming, i.e. the DEA method, is used for determining the optimum value of the dummy variable with function criteria:

$\max \sum_{j=1}^{k} R_{i j} \cdot v_{j}=z_{i(i)} i=1,2, \ldots, n$

This gives an $n$ set of optimal values of dummy variables $\left(v_{i 1}, v_{i 2}, \ldots, v_{i k}\right)$, for which the derived indicators are calculated for each element of the set:

$z_{h(i)}=\sum_{j=1}^{k} R_{h j} \cdot v_{h j}, i, h=1,2, \ldots, n$

where:

$\mathrm{z}_{\mathrm{h}(\mathrm{i})}:$ Derived indicator 
$\mathrm{v}_{\mathrm{hj}}$ : Dummy variables that correspond to certain indicators.

The average value of the derived indicators for each element is the geometric mean:

$D_{i}=\left(\prod_{h=1}^{n} z_{h(i)}\right)^{\frac{1}{n}}$

With the explanation:

$\mathrm{D}_{i}:$ Geometric mean

$\mathrm{z}_{\mathrm{h}(\mathrm{i})}$ : Derived indicator

Standardization of the derived indicators is performed:

average value: $\bar{D}=\frac{1}{n} \cdot \sum_{i}^{n} D_{i}$

deviation: $\sigma=\sqrt{\frac{1}{n} \cdot \sum_{i=1}^{n}\left(D_{i}-\bar{D}\right)^{2}}$

standardized value: $\mathrm{S}_{i}=\frac{\mathrm{D}_{i}-\overline{\mathrm{D}}}{\sigma}$

Calculating the average deviation of the initial values of indicators:

The average value of the indicator: $\bar{P}_{j}=\frac{1}{n} \sum_{i}^{n} P_{i j}$

$\bar{P}_{j}:$ Average values of original indicators

$P_{i j}$ : Original value of indicators

The deviation of the initial values of parameters is adjusted so that the average value is 100 :

$$
\sigma_{j}=\left[\frac{1}{n} \cdot \sum_{i=1}^{n}\left(\frac{P_{i j}}{\bar{P}_{j}} \cdot 100-100\right)^{2}\right]^{\frac{1}{2}}
$$

The average deviation of the original value of the indicator is calculated as the geometric mean to the formula:

deviation of the average value: $\sigma_{p}=\left(\prod_{j=1}^{k} \sigma_{j}\right)^{\frac{1}{k}}$ 
Standardized derived indicators are corrected with an average deviation of the initial values of indicators:

$$
\mathrm{K}_{i}=\mathrm{S}_{\mathrm{i}} \cdot \sigma_{\mathrm{p}}+10 \odot
$$

where:

$\mathrm{K}_{\mathrm{i}}$ : Final value of DEA index points.

The obtained values of the DEA index points $\mathrm{K}_{i}$ indicate the relative position of a given element in the set and are in line with the size of the original variables. The meaning of the points obtained is in accordance with the meaning of initial variables; i.e., if the initial variables indicated a better position of the elements of a set, it was shown by the obtained points.

The study, using the described methodology first, and based on initial data for the given indicators, calculated the DEA indices of the competitiveness of the higher education of 26 countries of the European Union, Serbia, AP Vojvodina (as a European region), Croatia and the FYR of Macedonia for the period from 2006 to 2010. The indices for Serbia and AP Vojvodina were calculated by the current model of investment in higher education [14]. The current model of investment is based on a formula with exclusive entrance criteria (the number of students enrolled for the first time, the number of teaching and non-teaching staff) in the allocation of budgetary resources for public institutions of higher education.

Thereafter, the authors applied a new investment model in higher education [15] to the baseline data for these indicators of competitiveness, which refer to Serbia and AP Vojvodina, ex post, in the same conditions. A new investment model in higher education is based on a formula that contains a combination of input - output criteria (the number of first time enrolments and the number of graduates, the proportional cost per student) in the allocation of investment, budgetary resources per student in study programs in higher education. By calculating investment costs per student in a study program and increasing the number of state-funded students, a new investment model, in the long term, encourages the employment of graduates. The faster employment of graduates of higher education through planning is a qualitative feature of the new model of investment in higher education relating to the results of its application. The aim and purpose of the new model of investment is the analysis of its influence on the changes in the competitiveness ranking of higher education of Serbia and AP Vojvodina, as a European region. 


\section{The Research Results}

\subsection{The DEA Index of Competitiveness of Selected Countries in Europe, Serbia and AP Vojvodina for the Period from 2006 to 2010}

Using the described methodology, based on the initial indicators of competitiveness, the DEA index of competitiveness of higher education and their ranking was calculated for the 26 countries of the European Union, Serbia, AP Vojvodina (as a European region), Croatia and FYR Macedonia for the period from 2006 to 2010, and the data are shown in Table 1.

Table 1

DEA competitiveness index of higher education and ranking of selected European countries, Serbia and AP Vojvodina, in the period from 2006 to 2010

\begin{tabular}{|c|c|c|c|c|c|c|c|c|c|c|c|}
\hline \multirow[t]{2}{*}{$\mathrm{No}$} & \multirow[b]{2}{*}{$\begin{array}{l}\text { Country } \\
\text { /Region }\end{array}$} & \multicolumn{2}{|c|}{2006} & \multicolumn{2}{|c|}{2007} & \multicolumn{2}{|c|}{2008} & \multicolumn{2}{|c|}{2009} & \multicolumn{2}{|c|}{2010} \\
\hline & & $\begin{array}{l}\text { DEA } \\
\text { index }\end{array}$ & Rank & \begin{tabular}{|l|} 
DEA \\
index \\
\end{tabular} & Rank & $\begin{array}{l}\text { DEA } \\
\text { index }\end{array}$ & Rank & $\begin{array}{l}\text { DEA } \\
\text { index }\end{array}$ & Rank & $\begin{array}{l}\text { DEA } \\
\text { index }\end{array}$ & Rank \\
\hline 1 & Serbia & 57.58 & 30 & 56.60 & 30 & 59.43 & 30 & 56.19 & 30 & 55.52 & 30 \\
\hline 2 & $\begin{array}{l}\text { AP } \\
\text { Vojvodina }\end{array}$ & 59.92 & 29 & 61.74 & 29 & 64.51 & 29 & 64.17 & 29 & 59.95 & 29 \\
\hline 3 & Croatia & 86.07 & 26 & 87.87 & 26 & 90.74 & 24 & 92.06 & 23 & 88.27 & 26 \\
\hline 4 & \begin{tabular}{|l} 
FYR \\
Macedonia
\end{tabular} & 70.61 & 28 & 71.50 & 28 & 69.38 & 28 & 76.01 & 28 & 77.45 & 28 \\
\hline 5 & Belgium & 98.98 & 19 & 97.64 & 20 & 99.24 & 20 & 99.51 & 19 & 103.04 & 12 \\
\hline 6 & Bulgaria & 94.67 & 21 & 99.51 & 19 & 102.67 & 16 & 103.46 & 14 & 98.63 & 20 \\
\hline 7 & Czech Rep. & 108.16 & 12 & 109.10 & 13 & 109.19 & 10 & 110.62 & 9 & 109.74 & 11 \\
\hline 8 & Denmark & 121.52 & 1 & 116.69 & 1 & 116.84 & 2 & 117.36 & 2 & 117.05 & 3 \\
\hline 9 & Germany & 104.64 & 15 & 107.10 & 14 & 111.32 & 6 & 114.38 & 5 & 113.04 & 6 \\
\hline 10 & Estonia & 112.49 & 8 & 111.94 & 7 & 108.04 & 13 & 101.23 & 17 & 99.92 & 18 \\
\hline 11 & Ireland & 114.90 & 4 & 112.29 & 6 & 109.37 & 9 & 103.53 & 13 & 102.03 & 14 \\
\hline 12 & Greece & 89.54 & 25 & \begin{tabular}{|l|}
89.08 \\
\end{tabular} & 25 & 86.81 & 27 & 87.73 & 27 & 88.20 & 27 \\
\hline 13 & Spain & 107.99 & 13 & 106.10 & 15 & 104.16 & 15 & 100.11 & 18 & 99.82 & 19 \\
\hline 14 & France & 98.25 & 20 & 97.56 & 21 & 100.18 & 19 & 102.30 & 16 & 100.97 & 16 \\
\hline 15 & Italy & 93.98 & 22 & 93.40 & 23 & 94.97 & 23 & 96.44 & 22 & 95.91 & 23 \\
\hline 16 & Cyprus & 105.07 & 14 & 109.52 & 11 & 111.46 & 5 & 112.90 & 7 & 113.51 & 5 \\
\hline 17 & Latvia & 111.53 & 9 & 112.82 & 5 & 108.67 & 12 & 96.98 & 20 & 97.17 & 21 \\
\hline 18 & Lithuania & 102.38 & 16 & 103.19 & 16 & 96.81 & 21 & 89.78 & 26 & 90.41 & 25 \\
\hline 19 & Hungary & 91.36 & 23 & 89.17 & 24 & 88.21 & 25 & 89.91 & 25 & 91.87 & 24 \\
\hline 201 & Malta & 89.89 & 24 & 95.67 & 22 & 101.67 & 18 & 104.14 & 12 & 102.77 & 13 \\
\hline
\end{tabular}




\begin{tabular}{|l|l|c|c|c|c|c|c|c|c|c|c|}
\hline 21 & Netherlands & 116.64 & 3 & 115.57 & 2 & 117.20 & 1 & 120.28 & 1 & 118.37 & 1 \\
\hline 22 & Austria & 110.17 & 11 & 110.52 & 9 & 112.78 & 4 & 115.29 & 3 & 115.68 & 4 \\
\hline 23 & Poland & 81.80 & 27 & 86.71 & 27 & 87.36 & 26 & 90.87 & 24 & 96.81 & 22 \\
\hline 24 & Portugal & 111.23 & 10 & 110.54 & 8 & 110.88 & 7 & 112.50 & 8 & 110.52 & 9 \\
\hline 25 & Romania & 100.04 & 18 & 99.90 & 18 & 95.77 & 22 & 96.84 & 21 & 100.02 & 17 \\
\hline 26 & Slovenia & 114.38 & 5 & 113.05 & 4 & 109.07 & 11 & 109.44 & 10 & 111.05 & 8 \\
\hline 27 & Slovakia & 100.59 & 17 & 101.29 & 17 & 102.24 & 17 & 102.48 & 15 & 101.91 & 15 \\
\hline 28 & Sweden & 118.83 & 2 & 114.55 & 3 & 114.05 & 3 & 114.40 & 4 & 117.52 & 2 \\
\hline 29 & $\begin{array}{l}\text { United } \\
\text { Kingdom }\end{array}$ & 114.20 & 6 & 110.20 & 10 & 110.56 & 8 & 113.27 & 6 & 112.55 & 7 \\
\hline 30 & Finland & 112.59 & 7 & 109.19 & 12 & 106.43 & 14 & 105.83 & 11 & 110.31 & 10 \\
\hline
\end{tabular}

Source: Eurostat (2010), Statistical Office of the Republic of Serbia (2011), and author's

own calculations

Based on the data in Table 1, it can be concluded that the greatest competitiveness of higher education among the 30 surveyed countries / regions in Europe is in countries where the output criteria and factors involving increased amounts of budget investment are the basis of models of investment in higher education. Denmark is in the first place in 2006 and 2007, and the Netherlands is in the first place in the next three years analysed. Listed after them is another Scandinavian country, Sweden, which in the given five-year period is in the second or the third place, except in 2009 when the country was listed in the fourth place. In Sweden, in recent years, stricter connections were enforced between academic progress and budget grants, which is favourable to the further development of higher education and its competitiveness.

Among the other highly industrialized countries, there is significant competitiveness of higher education in the five-year period analysed, in the cases of Great Britain, Austria and Germany. In these countries, the increased demand for higher education scholarships was matched by higher tuition prices. A special feature of these industrialized countries is that in the last three years analysed, i.e. in 2008, 2009 and 2010, they significantly improved the competitiveness of higher education, analysed using the competitiveness index. On the other hand, two highly developed industrial countries of the European Union, Italy and France, have low competitiveness of higher education, primarily due to lower budget allocations per student compared to other developed countries of the European Union. This especially applies to Italy, which was located at the $22^{\text {nd }}$ or $23^{\text {rd }}$ place in the five-year period, out of the 30 European countries / regions analysed.

It is important to mention the index of higher education competitiveness of Ireland and Cyprus, which are seeking to step up their social and economic development based primarily on the principle of the "knowledge society" [18]. While in Cyprus, competitiveness was on the rise in the period from 2006 to 2010, in Ireland, affected by the economic crisis, it was quite the opposite: there the competitiveness of higher education decreased in the five-year period analysed. 
The lowest competitiveness of higher education among the analysed countries of the European Union was found in Greece, in the $25^{\text {th }}$ position in 2007 and 2006 and in the $27^{\text {th }}$ position in the other three years of the five-year period. The index points of the most competitive countries and of the countries with the lowest competitiveness indicate that there are clearly noticeable disparities in competitiveness of higher education among the analyzed countries / regions, because the difference is more than 60 percentage points.

In the countries of former Yugoslavia, Slovenia was highly ranked in all years of the five-year period. This especially applies to 2006 when it ranked fifth, and even more so in 2007 when it ranked fourth. Croatia ranks low in 2006, 2007 and 2010, at the $26^{\text {th }}$ place, in 2008 at the $23^{\text {rd }}$ place and in 2009 at the $24^{\text {th }}$ place in the fiveyear period analysed. The lowest competitiveness of higher education among the countries of former Yugoslavia, according to the methodology applied, is found in FYR Macedonia. While in Slovenia the applied investment model in higher education is characterized by a high degree of financial autonomy of institutions, as well as a combination of input and output criteria in the model formula, in the current investment model in Serbia, as well as the investment model of Croatia and FYR Macedonia, there is a low level of financial autonomy of institutions and mostly input criteria in the allocation of budgetary funds. These facts, related to the performance of the investment model, affect the competitiveness of the higher education of these countries.

Because of the least favourable initial values of the indicators of the competitiveness of higher education, the competitiveness of the higher education of Serbia and AP Vojvodina is the lowest of all the European countries analysed. According to the competitiveness of higher education, analyzed using the existing model of investment in which the criteria are based on inputs, Serbia is at the $30^{\text {th }}$ place in all years of the five-year period, and AP Vojvodina is at the penultimate $29^{\text {th }}$ place. This data indicates the need to implement a new investment model for the higher education system in Serbia to improve investment and to increase the number of state-funded students and graduates employed, and thus to contribute to an increase of higher education competitiveness.

\subsection{DEA Competitiveness Index, Serbia and AP Vojvodina, for the Period from 2006 to 2010 after the Implementation of the New Investment Model}

Based on the applied methodology, the DEA indices were calculated and the rankings of the competitiveness of higher education in Serbia and AP Vojvodina were determined and compared to the 26 countries of the European Union, Croatia and FYR Macedonia, after the implementation of the new investment model [15]. These are shown in Table 2. 
Table 2

DEA competitiveness index of higher education and ranking of selected European countries, Serbia and AP Vojvodina, in the period from 2006 to 2010 after the implementation of the new investment model

\begin{tabular}{|c|c|c|c|c|c|c|c|c|c|c|c|}
\hline \multirow[t]{2}{*}{ No } & \multirow[b]{2}{*}{$\begin{array}{l}\text { Country } \\
\text { /Region }\end{array}$} & \multicolumn{2}{|c|}{2006} & \multicolumn{2}{|c|}{2007} & \multicolumn{2}{|c|}{2008} & \multicolumn{2}{|c|}{2009} & \multicolumn{2}{|c|}{2010} \\
\hline & & \begin{tabular}{|l|} 
DEA \\
index
\end{tabular} & Rank & $\begin{array}{l}\text { DEA } \\
\text { index }\end{array}$ & Rank & \begin{tabular}{l|} 
DEA \\
index
\end{tabular} & Rank & \begin{tabular}{|l|} 
DEA \\
index
\end{tabular} & Rank & \begin{tabular}{|l|} 
DEA \\
index
\end{tabular} & Rank \\
\hline & Serbia & 61.18 & 30 & 57.75 & 30 & 62.70 & 30 & 59.41 & 30 & 58.72 & 30 \\
\hline 2 & $\begin{array}{l}\text { AP } \\
\text { Vojvodina }\end{array}$ & 62.94 & 29 & 62.71 & 29 & 67.45 & 28 & 66.94 & 29 & 62.68 & 29 \\
\hline 3 & Croatia & 84.93 & 26 & 87.50 & 26 & 89.94 & 24 & 91.33 & 23 & 87.24 & 26 \\
\hline 4 & $\begin{array}{l}\text { FYR } \\
\text { Macedonia }\end{array}$ & 68.63 & 28 & 70.79 & 28 & 67.41 & 29 & 74.38 & 28 & 75.74 & 28 \\
\hline 5 & Belgium & 98.53 & 19 & \begin{tabular}{|l|}
97.46 \\
\end{tabular} & 20 & \begin{tabular}{|l|}
98.86 \\
\end{tabular} & 20 & 99.13 & 19 & 102.85 & 12 \\
\hline 6 & Bulgaria & 94.01 & 21 & 99.38 & 19 & 102.50 & 16 & 103.33 & 14 & 98.20 & 20 \\
\hline 7 & Czech Rep. & 108.27 & 12 & 109.18 & 13 & 109.36 & 10 & 110.86 & 9 & 109.98 & 11 \\
\hline 8 & Denmark & 122.33 & 1 & 116.91 & 1 & 117.39 & 2 & 117.96 & 2 & 117.71 & 3 \\
\hline 9 & Germany & 104.58 & 15 & 107.16 & 14 & 111.70 & 6 & 114.92 & 4 & 113.57 & 6 \\
\hline 10 & Estonia & 112.74 & 8 & 112.03 & 7 & 108.03 & 13 & 100.85 & 17 & 99.44 & 18 \\
\hline & Ireland & 115.33 & 4 & 112.40 & 6 & 109.52 & 9 & 103.37 & 13 & 101.77 & 14 \\
\hline 12 & Greece & 88.43 & 25 & 88.66 & 25 & 85.61 & 27 & 86.56 & 27 & 86.93 & 27 \\
\hline & Spain & 108.04 & 13 & 106.10 & 15 & 104.04 & 15 & 99.76 & 18 & 99.43 & 19 \\
\hline 14 & France & 97.78 & 20 & 97.40 & 21 & 99.89 & 19 & 102.13 & 16 & 100.70 & 16 \\
\hline & Italy & 93.27 & 22 & 93.14 & 23 & 94.39 & 23 & 95.94 & 22 & 95.34 & 23 \\
\hline 16 & Cyprus & 105.04 & 14 & 109.63 & 11 & 111.80 & 5 & 113.28 & 7 & 113.98 & 5 \\
\hline 17 & Latvia & 111.68 & 9 & 112.91 & 5 & 108.64 & 12 & 96.31 & 20 & 96.47 & 21 \\
\hline 18 & Lithuania & 102.00 & 16 & 103.06 & 16 & 96.10 & 21 & 88.65 & 26 & 89.21 & 25 \\
\hline 19 & Hungary & 90.44 & 23 & 88.79 & 24 & \begin{tabular}{|l|}
87.19 \\
\end{tabular} & 25 & 88.99 & 25 & 90.99 & 24 \\
\hline 20 & Malta & 89.02 & 24 & 95.50 & 22 & 101.56 & 18 & 104.15 & 12 & 102.70 & 13 \\
\hline 21 & Netherlands & 117.21 & 3 & 115.78 & 2 & 117.82 & 1 & 121.08 & 1 & 119.16 & 1 \\
\hline 22 & Austria & 110.40 & 11 & 110.64 & 9 & 113.17 & 4 & 115.83 & 3 & 116.31 & 4 \\
\hline 23 & Poland & 80.26 & 27 & 86.23 & 27 & 86.16 & 26 & 89.85 & 24 & 96.08 & 22 \\
\hline 24 & Portugal & 111.50 & 10 & 110.65 & 8 & 111.17 & 7 & 112.90 & 8 & 110.84 & 9 \\
\hline 25 & Romania & 99.65 & 18 & 99.75 & 18 & 95.10 & 22 & 96.21 & 21 & 99.54 & 17 \\
\hline 26 & Slovenia & 114.69 & 5 & 113.13 & 4 & 109.05 & 11 & 109.47 & 10 & 111.22 & 8 \\
\hline 27 & Slovakia & 100.25 & 17 & 101.18 & 17 & 101.99 & 17 & 102.23 & 15 & 101.62 & 15 \\
\hline 28 & Sweden & 119.46 & 2 & 114.71 & 3 & 114.42 & 3 & 114.80 & 5 & 118.18 & 2 \\
\hline & \begin{tabular}{|l} 
United \\
Kingdom
\end{tabular} & 114.62 & 6 & 110.29 & 10 & 110.79 & 8 & 113.72 & 6 & 112.96 & 7 \\
\hline 30 & Finland & 112.80 & 7 & 109.19 & 12 & 106.26 & 14 & 105.66 & 11 & 110.43 & 10 \\
\hline
\end{tabular}

Source: Eurostat (2010), Statistical Office of Serbia (2011), and author's own calculations 
Based on the data presented in Table 2, it can be concluded that with the implementation of a new investment model, the competitiveness of higher education of Serbia is increased, compared to the selected European countries in each year of the analysed period of five years: in 2006 by 3.60 percentage points, in 2007 by 1.15 , in 2008 by 3.27 , in 2009 by 3.22 and in 2010 by 3.20 percentage points.

In AP Vojvodina there are similar trends, but with lower growth of the competitiveness index of higher education. The competitiveness of higher education in AP Vojvodina, as a European region, with the implementation of a new investment model in higher education is also improved, because the initial index points using the new model of investment in 2006 are higher by 3.02, in 2007 by 0.97 , in 2008 by 2.94, in 2009 by 2.77 and in 2010 by 2.73 percentage points. It is noted that, due to the low budgetary investment in higher education in AP Vojvodina and the fewer students per 1,000 residents, by using the new investment model and methodology described, there was a lower pace of the growth of the competitiveness index of higher education in relation to the growth of the same index in Serbia as a whole.

According to the new model of investment, there was no change in the rank of Serbia in relation to the selected European countries and AP Vojvodina, as a European region, since in all years of the five-year period analysed, the competitiveness ranking of Serbia remained at the $30^{\text {th }}$ place. It is similar with AP Vojvodina, which, using the new investment model in higher education and compared to selected European countries improved its competitiveness ranking in 2008 only.

Based on these data and facts, it is shown that the application of the new investment model contributed to increasing the competitiveness of higher education in Serbia and in AP Vojvodina, and its application is necessary and expedient.

\section{Conclusion}

The results of the analysis presented in this paper suggest an unsatisfactory competitiveness of higher education of Serbia and AP Vojvodina, as a European region. The competitiveness is not adequate to the need and dynamics of development of higher education in transition countries like Serbia. Stronger social and economic development is conditioned by creating a knowledge based society, and by learning and innovation, which includes the need for further development of higher education in Serbia and an increase of its competitiveness. Therefore, the higher education system should direct its educational and research capacity at increasing development needs of society and the economy.

Facts and figures obtained in this study suggest the need to intensify efforts and resources in the field of higher education with the aim of increasing the competitiveness of higher education in Serbia and AP Vojvodina, in relation to the 
countries of the European Union. On the basis of these results, the educational authorities in the higher education of Serbia are suggested to implement a new investment model. The application of the new investment model would increase the volume of investment in higher education, the number of state-funded students, the employability of graduates, and thus the competitiveness of higher education.

The results indicate that a unified approach to strategy development and higher education competitiveness in the European Union is necessary. This is because there are very large differences in the competitiveness of higher education among the European countries analysed. The creation of a knowledge based society implies a higher share of highly educated population. Thus, the need to increase the quality and quantity as well as the international competitiveness of higher education is one of the basic issues for which authorities in the higher education sector in European countries should find appropriate solutions in the future.

Restrictions regarding the research are related to the fact that this research did not analyse the higher education competitiveness of the EU as a whole. There are also limitations regarding the indicators of competitiveness of higher education used to calculate the DEA competitiveness index. Some factors which are not only in the spheres of policy makers and development strategy of higher education affect the change of these indicators, such as demographic changes, the socio-economic status of the population, the interest in studying in the function of labour market trends, and the like. On the other hand, there is the issue of unemployment or employment reduction due to the effects of the economic and debt crisis and its impact on the analysed indicators.

Bearing this in mind, the directions for further research will be related to the DEA analysis of the competitiveness index of higher education by researching other relevant indicators of competitiveness of higher education, such as the number of graduates in the total number of students and higher education participation in total employment.

\section{References}

[1] B. Clark: The Higher Education System: Academic Organization in Cross National Perspective, Berkeley, University California Press, 1983

[2] B. Jacobs, F. Ploeg: Guide to Reform of higher Education: A European Perspective, Discussion paper series No. 5327, Industrial organization and public policy, Centre for Policy Research, London, 2005

[3] C. M. Hoxby: How the Changing Market Structure of U.S. Higher Education Explains College Tuition, NBER, Working Paper 6323, 1997

[4] C. Lentner: The Competitiveness of Hungarian University-based Knowledge Centres in European Economic and Higher Education Area, Transformations in Business \& Economics, Vol. 6, No. 2 (12), 2007, pp. 87-99 
[5] E. Canton, et al: Higher Education Reform: Getting the Incentives Right. CPB/CHEPS University of Twente, 2001

[6] E. Del Rey, M. Racionero: Financing Schemes for Higher Education, European Journal of Political Economy, Vol. 26, No. 1, 2010, pp. 104-113

[7] E. Egron - Polak: Which Way Ahead for IAU? The Bimonthly Newsletter of the International Association of Universities, Vol. 7, No. 5, 2001, pp. 1-3

[8] Eurostat: Employment statistic, 2010

http://epp.eurostat.ec.europa.eu/portal/page/portal/employment_unemploym ent_lfs/data/database

[9] Eurostat:Population statistics, 2010

http://epp.eurostat.ec.europa.eu/portal/page/portal/population/data/database

[10] Eurostat:Tertiary education statistic, 2010

http://epp.eurostat.ec.europa.eu/statistics_explained/index.php/Tertiary_edu cation_statistics

[11] J. Eicher: The Costs and financing of Higher Education in Europe, European Journal of Education, Vol. 33, No. 1, 1998, pp. 31-39

[12] J. Eicher, T. Chevailler: Rethinking the Financing of Post-Compulsory Education. Higher Education in Europe, Vol. 27, No. 1-2, 2002, p. 69

[13] J. G., Mora, L. Vila: The Economics of Higher Education. In: The Dialogue between Higher Education Research and Practice, ed. Roddy Begg, 121-134, Kluwer Academic Publishers, 2003

[14] J. Kabók: Investment Models for Higher Education, Annals of the Faculty of Economics in Subotica, Vol. 46, No. 24, 2010, pp. 155-168

[15] J. Kabók, V. Djaković, G. Andjelić: Investment Model Aimed at Raising Competitiveness of Higher Education, Proceedings XV International Scientific Conference on Industrial Systems, Novi Sad, Serbia, September 14-16 2011, pp. 446-450

[16] J. Lowter: The Quality of Croatian Formal Education System. In: Competitiveness of Croatian workforce, Institute of Public Finance, Zagreb, 2004, pp. 13-25

[17] K. Dobrai, F. Farkas, Zs. Karoliny, J. Poór: Knowledge Transfer in Multinational Copmanies - Evidence from Hungary, Acta Polytechnica Hungarica, Vol. 9, No. 3, 2012, pp. 149-161

[18] Lisbon European Council 23 and 24 March 2000: Presidency Conclusions, 2000

http://www.europarl.europa.eu/summits/lis1_en.htm\#1

[19] L. Weber, S. Bergan: The Public Responsibility for Higher Education and Research, Council of Europe Higher Education Series No. 2, Council of Europe, Strasbourg, 2005 
[20] N. Barr: Higher Education Funding, Oxford Review of Economic Policy, Oxford University Press, Vol. 20, No. 2, 2004, pp. 264-283

[21] R. Huggins: Designing a European Competitiveness Index: Measuring the Performance and Capacity of Europe's Regions and Nations', European Regional Economic Forum, Nova Gorica, Slovenia, October 27-28, 2005

[22] Statistical Office of the Republic of Serbia, Statistical Almanac of Serbia, Belgrade, 2010

[23] T. Berchem: The University as an Agora - Based on Cultural and Academic Values. Higher Education in Europe, Vol. 31, No. 4, 2006, pp. 395-396

[24] The Bologna Declaration of 19 June 1999: Joint declaration of the European Ministers of Educatin, 1999

http://www.bologna-bergen2005.no/Docs/00Main_doc/990719BOLOGNA_DECLARATION.PDF

[25] UNESCO Access, Values, Quality and Competitiveness, UNESCO Forum on Higher Education in the Europe Region, Bucharest, Romania, May 2124, 2009 